\title{
Revisiting Egypt's Energy Policy
}

Tarek H. Selim, (Email: tselim@aucegypt.edu), American University in Cairo, Egypt

\begin{abstract}
Egypt's oil and gas sector is one of the most strategic sectors in the economy being the single largest industrial activity in the economy, with exports of crude oil and petroleum products constituting $40 \%$ of Egypt's export revenues and 20\% of its GDP. However, Egypt is currently trapped between dwindling oil production and increasing domestic consumption, a fact which threatens the country to become a net importer of crude oil as well as deprive it of strongly needed foreign exchange. Yet, Egypt has proven natural gas reserves and its future energy outlook seems to be more affiliated with natural gas especially for future export potential. Given these conditions, a restructuring of the sector is necessary for sustainable development. Suggested strategies in line with Egypt's development efforts are outlined including gradual reduction of energy subsidies and their expected impacts on the economy.
\end{abstract}

\section{INTRODUCTION}

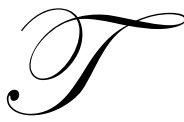

he oil and gas sector is considered to be one of the most important and strategic sectors in the Egyptian economy. The Egyptian government gives the sector high priority and has outlined the following strategic objectives for its enhacement (Ministry of Petroleum): ${ }^{1}$ (1) increase Egypt's crude oil and natural gas reserves by encouraging onshore and offshore exploration, (2) better scientific management of crude oil and natural gas reserves and production, (3) protect Egypt's environment and ecological systems, (4) support and encourage the involvement of the Egyptian private business in the Petroleum sector.

In 2003, the production of petroleum constituted around $8 \%$ of GDP, which was the largest single industrial activity. During the first part of 2005 the export of crude oil and petroleum products constituted $40 \%$ of Egypt's export returns and around $20 \%$ of its GDP. ${ }^{2}$

Egypt experienced promising growth rates in the 1990s. Unfortunately such a growth trend did not continue with the turn of the $21^{\text {st }}$ Century and Egypt's economy witnessed declining growth rates in 2001 and 2002. However, in 2004 the Egyptian economy started on a slow road to recovery with GDP growing at 3.6\% in 2004 as compared to $2.9 \%$ in $2003 .^{3}$

\section{HISTORICAL BACKGROUND}

Egypt's production of crude oil during 2004 was around 594,000 barrels per day (bpd), lower than the 2003 production level of 618,000 bpd (a decrease of 3.9\%), yet a far cry from 1996 peak of 922,000 bpd. The majority of the current fields have reached their maturity and have begun their downward operational decline. The government is trying to overcome this maturity problem by increased investments to enhance the production of oil, increased exploration activity in the hope of discovering new fields while at the same time carefully curbing consumption

\footnotetext{
${ }^{1}$ Ministry of Petroleum official website http://www.emp.gov.eg/ENGLISH/objectives.html accessed 10.11.2005.

${ }^{2}$ U.S. Department of Energy, Energy Information Administration, Country Analysis briefs: Egypt, May 2005 www.eia.gov/emeu/cabs/egypenv.html, accessed December 2005.

${ }^{3}$ International Energy Outlook, U.S. Energy Information Administration, October 2005, www.eia.doe.gov/emeu/cabs/carbonemiss/chapter5.html, accessed October 2005.
} 
through the slow withdrawal of subsidies and the encouragement of the use of compressed natural gas (CNG) as an alternative fuel. ${ }^{4}$

Egypt continues to be a net exporter of crude oil and petroleum products, however due to increased domestic consumption net exports have declined over recent years. However the substantial increases in world prices which are now close to $\$ 60 / \mathrm{b}$, have made up for this decline, with oil revenues actually witnessing an increase. With respect to liquefied natural gas (LNG), Egypt started to export in early 2005 and hopes to increase such exports even further with the expected expansion of capacity due to materialize by end of $2005 .^{5}$

\section{PRODUCTION AND CONSUMPTION}

Egypt's golden years, in terms of net export earnings were in the mid 1990s. Production then declined sharply indicating field maturity, with the problem being accentuated by a steady rise in domestic consumption. The following graph (Figure 1) shows the growth path of Egypt's oil production and consumption between 1980 and $2004{ }^{6}$

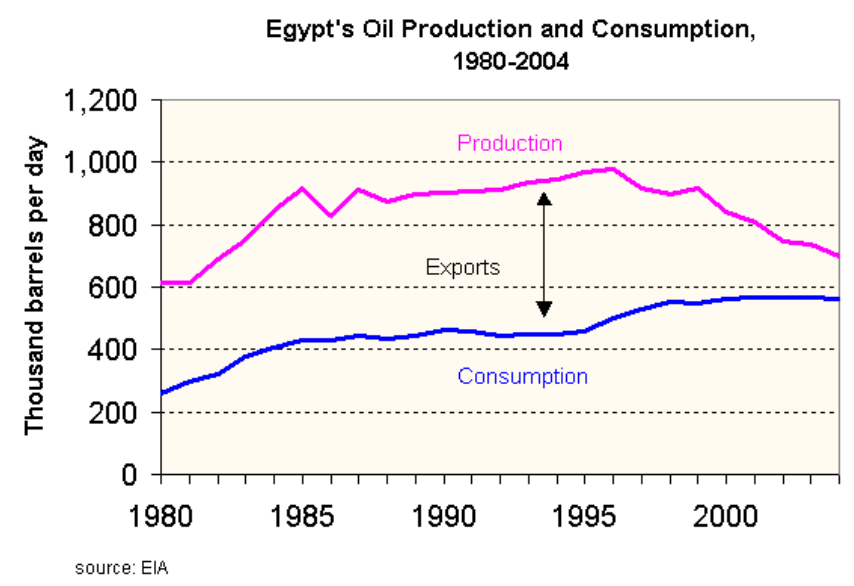

Figure 1: Egypt's Oil Production And Consumption, 1980-2004 (Energy Information Administration)

Net oil exports steadily increased over the last 25 years, because the rate of growth of oil production exceeded the rate of growth in oil consumption. Although domestic consumption has leveled off in recent years, it is expected that in the short run, Egypt would become a net importer of oil. Hence Egypt is deprived of possible foreign currency earnings as consumption erodes any possible exports and swallows the already declining production. Furthermore, Egypt will also probably have to draw on its foreign currency reserves, or increase its domestic indebtedness to maintain a system that is over-ridden by heavily-subsidized domestic oil and gas products. Oil and gas subsidies are rife in both the consumer as well as the intermediate sectors and are thus intertwined in all the productive activities. ${ }^{7}$ Egypt is trapped with a tradeoff between exporting crude oil and exporting refined oil products. If it wants to maintain being a crude oil exporter then it would have to decrease the throughput to refineries and hence decrease is refined oil export revenues. The significance of the petrochemicals industry is further accentuated by the fact that natural gas is one of its primary inputs. Therefore, Egypt's natural gas reserves provide it with an excellent comparative advantage for the production of petrochemicals. Unfortunately, production of petrochemical products only covers a third of domestic demand. This should encourage the government to enhance this sector in a bid to improve its deficit

\footnotetext{
${ }^{4}$ The Petroleum Industry in Egypt: Investment \& Prospects, American Chamber of Commerce in Egypt (Am Cham), Business Studies Series, December 2003.

${ }^{5}$ Ibid.

${ }^{6}$ U.S. EIA Ibid

7 Apache Egypt's Contribution to the Egyptian National Economy, Rodrigo Seda Ph.D., The American University in Cairo, 2005, p. 27-28.
} 
situation. Furthermore, petrochemicals are strategic intermediate products to many industries, and strengthening that sector would strengthen Egypt's industrial base and ensure a sustained raw material supply chain. ${ }^{8}$ The Egyptian government undertook a long term investment plan incorporating around $\$ 10$ billion in order to develop the petrochemical industry by the year 2021. The plan is envisaged to take full advantage of Egypt's gas reserves to maximize value added benefits. A byproduct of this ambitious plan is the import substitution of the current $\$ 3$ billion bill that Egypt foots to cover petrochemical imports. ${ }^{9}$

The natural gas sector is one of the fastest growing sectors in the Egyptian economy and production increased more than two-fold between 1999 and $2003^{10}$ and almost 1000-fold over the last 20 years. Egypt's future energy outlook therefore seems to be more and more affiliated with natural gas, which is currently Egypt's main source of energy. It is worth mentioning that the substantial increase in the production of natural gas liquids helped to iron out some of the negative repercussions of the reduction of crude oil production. The average daily production of natural gas during 2004 was 3.6 billion cubic feet per day (bcf/d). ${ }^{11}$ Egypt's proven natural gas reserves are estimated to be over 65 trillion cubic feet (Tcf), with actual reserves probably amounting to almost double that volume. Total gas consumption took off when thermal power plants converted from oil to gas. These now constitute around $65 \%$ of total gas consumption. ${ }^{12}$ In 2001/2002, Egypt ranked third in worldwide natural gas consumption, with a daily consumption of 2.6 billion cubic feet (bcf). ${ }^{13}$

Around $84 \%$ of Egypt's electric generating capacity is thermal (natural gas), with the remaining $16 \%$ hydroelectric from the Aswan High Dam. The government has converted all oil-fired plants to run on natural gas as their primary fuel. ${ }^{14}$ With the expected growth in electricity demand in Egypt, the implications on the increased domestic demand of natural gas cannot be overlooked. Again, the question of fixed pricing and subsidization comes into focus and should be addressed.

In 2001, Egypt agreed with Jordan and Syria to extend its Sinai natural gas pipeline into Jordan. In 2003, the Egypt-Jordan gas pipeline at Taba was launched, and Egypt commenced export of natural gas. There are future plans to link it to Syria, Lebanon, Turkey and Cyprus. ${ }^{15}$ Egypt also has an initial agreement for the establishment of an oil and natural gas pipeline to Libya.

\section{OIL CONCESSIONS}

The Egyptian government, represented by the Ministry of Petroleum and its different agencies, exerts full control over the industry, and has a tight reign over all concessions whether for exploration, refining or selling, through the granting of oil concessions. The following diagram ${ }^{16}$ (Figure 2) outlines the energy agencies concerned with the structure of the oil and gas industry.

An oil concession can be public or private, and is a contract between the government and the exploring company, known as the concessionaire, which gives it the right to explore, produce, export and sell any oil or gas that it discovered in the field under concession, during the duration of the concession period. The concession also outlines all the legal aspects of both parties i.e. their rights and responsibilities. ${ }^{17}$ Oil concessions are granted after a

\footnotetext{
${ }^{8}$ Am Cham, Ibid, p.34.

${ }^{9}$ Middle East Economic Digest, Egypt: Petrochemicals, January 2003.

${ }^{10}$ Ibid.

11 Ibid.

${ }^{12}$ U.S. EIA, Ibid.

${ }^{13}$ World Energy Council, Energy in Egypt 2002, www.worldenergy.org/wec-geis/wec-info/structure-organisation/ea/cairo/ stats/eie.asp accessed November 2005.

${ }^{14}$ Ibid.

${ }^{15}$ U.S. EIA, Ibid.

${ }^{16}$ Am Cham, Ibid.p.9.

${ }^{17}$ H. Cattan: The Law of Oil Concessions in the Middle East and North Africa, Oceana Publications, Inc., Dobbs Ferry, New York, 1967, p. 20.
} 
competitive bidding process and legislative approval. Unfortunately, these procedures are bureaucratic in nature, take considerable time and do not have any deadline.

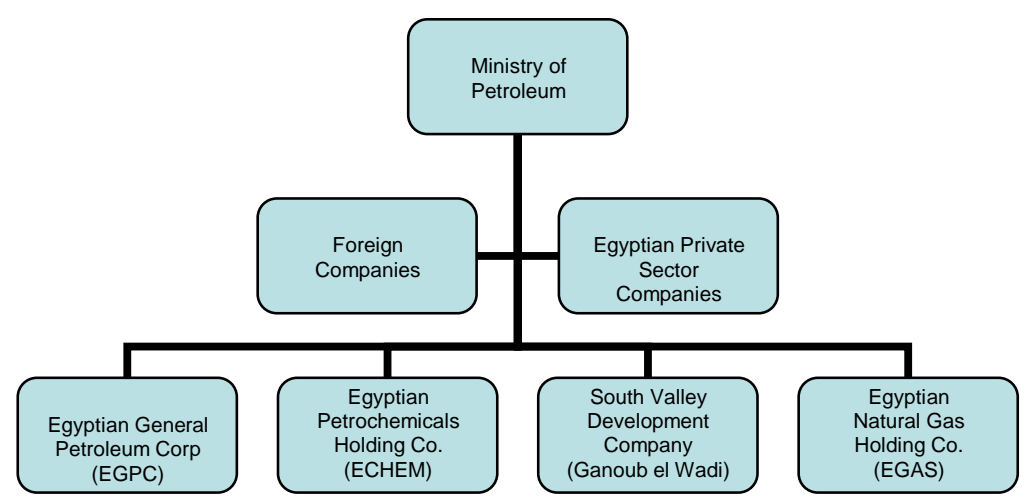

Figure 2: Operating Energy Agencies (American Chamber Of Commerce In Egypt)

\section{DEVELOPMENT INDICATORS}

Egypt's level of growth and development slightly improved as indicated by the Human Development Index (HDI) which rose from 0.608 in 1997 to 0.659 in 2002. Unfortunately, quantitatively GDP witnessed a decrease from $\$ 89.1$ billion in 1999 to $\$ 82.4$ billion in $2003 .{ }^{18}$ GDP per capita also fell from $\$ 1354$ in 2002 to $\$ 1220$ in $2003 .{ }^{19}$

The petroleum industry in Egypt is considered to be one of the major development catalysts due to the interest that it has stirred in this sector's investors. Local investments in the petroleum industry in 2001/02 amounted to around L.E. 7.8 million ( $\$ 1.7$ million) while foreign investment was around $\$ 2.1$ million. However since the oil and gas industry is a capital intensive industry, manpower in crude oil was only 33,300 workers in 2004, and in oil products was slightly less at around $30,300 .{ }^{20}$ It should be noted however, that since this is a highly capital intensive industry, it does not hold the key to Egypt's unemployment problem which lies in the range between $10 \%$ (official figures) and $25 \%$ (unofficial).

The oil and gas sector fulfills around 95\% of Egypt's energy requirements, distributed between oil (53\%) and natural gas $(42 \%){ }^{21}$ Electricity generation is the highest consumer of gas $(62.4 \%)$, followed by industry (26.2\%), Petroleum Industry $(9.4 \%)$ and residential and commercial users $(2 \%) .{ }^{22}$

Due to the discoveries of substantial natural gas reserves, Egypt currently has a potential comparative advantage. This should be further developed into a competitive advantage so that its export potential is maximized to the full.

One of the main critiques of the oil and gas industry is its high level of subsidies. Prices are extremely distorted and do not reflect international prices. Furthermore, subsidies carry with them a huge amount of public debt as well as external debt. The government announced that it in its 2003/04 budget it spent around L.E. 14 billion to cover petroleum subsidies (1US\$ is equivalent to 5.7 L.E.). ${ }^{23}$ It is ironic to note that oil and gas have been complementing each other, as well as other sectors in the economy. Whereas oil production is now dwindling in view

\footnotetext{
${ }^{18}$ Bertelsmann: http://www.bertelsmann-transformation-index.de

${ }^{19}$ UNDP: http://www.hdr.undp.org/statistics/data

${ }^{20}$ accessed 6.11.2005.

${ }^{21}$ Am Cham, Ibid, p.8.

${ }^{22}$ UNDP: http://www.undp.org/Egypt

${ }^{23}$ Am Cham, Ibid, 43.
} 
of maturing oil fields, gas production by contrast is enjoying its peak. Furthermore, since the oil and gas sector is heavily subsidized both to consumers as well as to intermediate industries, the oil and gas sector actually partially subsidizes all productive activity in the Egyptian economy. And while Egypt faces falling oil production from its mature oil fields, and hence declining revenues in spite of increasing international oil prices, domestic consumption might force it to become a net oil importer by 2005 or 2006. ${ }^{24}$ Unless Egypt reforms its existing pricing mechanism in the oil sector it would further augment a chronic problem.

\section{STRENGTHS, WEAKNESSES, OPPORTUNITIES, AND THREATS - SWOT ANALYSIS}

The following table summarizes the SWOT Analysis for the oil and gas industry in Egypt.

Table 1: SWOT Analysis For Egypt's Energy Sector

\begin{tabular}{|c|c|c|c|}
\hline STRENGTHS & WEAKNESSES & OPPORTUNITIES & THREATS \\
\hline $\begin{array}{l}\text { - *Existing joint ventures } \\
\text { with long term interests } \\
\text { in Egypt } \\
\text { - Government } \\
\text { encouragement of private } \\
\text { \& foreign investments } \\
\text { - Substantial gas reserves } \\
\text { (65 Tcf) } \\
\text { - Conversion from oil to } \\
\text { gas of most electric } \\
\text { plants \& public transport } \\
\text { - Sumed pipeline from Ain } \\
\text { Sukhna to Mediterranean } \\
\text { - Export pipeline to } \\
\text { Jordan }\end{array}$ & $\begin{array}{ll}\text { - } & \text { Maturity of oil fields } \\
\text { - } & \text { High domestic } \\
\text { Consumption } \\
\text { - } \\
\text { High capital Intensive } \\
\text { industry which does not } \\
\text { improve Egypt's current } \\
\text { unemployment problem } \\
\text { - Egypt not yet } \\
\text { established as a natural } \\
\text { gas exporter }\end{array}$ & $\begin{array}{ll}\text { - } & \text { New discoveries } \\
\text { - } & \text { New joint ventures } \\
\text { - } & \text { Foreign direct } \\
\text { - } & \text { Exvestments (FDI'S) } \\
\text { - } & \text { Potential gas export to } \\
& \text { Libya } \\
\text { - } & \text { Potential gas export to } \\
& \text { Syria, Lebanon \& } \\
& \text { Turkey }\end{array}$ & 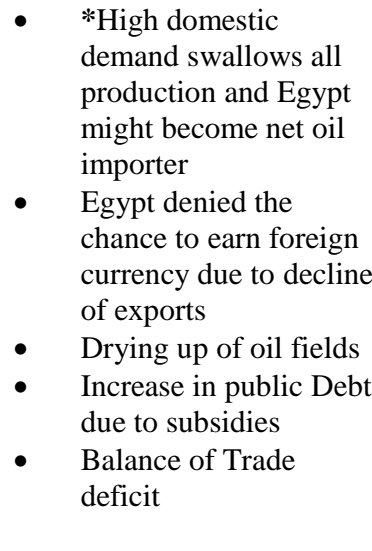 \\
\hline
\end{tabular}

\section{STRATEGIES FOR GROWTH}

Based on the previous analysis, the energy sector in Egypt needs major restructuring. In this section, simulataneous strategies for restructuring are proposed and discussed in some detail with the hope of a sustainable development future for oil and gas in Egypt. Table 3 outlines the proposed strategies and their expected impact.

The Egyptian government carries an inherited legacy of half a century of subsidization of basic goods and services. This has become the trademark of the social contract between the state and the Egyptian citizen. In Egypt a 34.4 fold income gap exists between the highest and lowest quintile, and the fact that more than $20 \%$ of all Egyptian families are considered poor ${ }^{25}$ makes subsidies of vital importance to their very existence and their access to affordable energy. The fact that $43.9 \%$ of Egyptian population falls below the $\$ 2 /$ day mark $^{26}$ further highlights the severity of the issue. The strategy suggested here is intended to promote a gradual transition from consumer subsidies on energy commodities to more sustainable energy production and distribution mechanisms at the local level.

\footnotetext{
${ }^{24}$ Apache Egypt's Contribution to the Egyptian National Economy, Ibid, p.28.

${ }^{25}$ UNDP, Egypt Human Development Database.

${ }^{26}$ Ibid.
} 
Table 3: Proposed Strategies And Their Expected Impact

\begin{tabular}{|l|}
\hline \multicolumn{1}{|c|}{ STRATEGY } \\
\hline 1. Reduction/Removal Of Energy Subsidy: \\
- \\
Establish a welfare system: conduct a comprehensive \\
survey to determine income status of the population and \\
accordingly allocate aid (monetary or in kind) to those in \\
need. \\
- Set long-term date to eliminate energy subsidies. \\
- Enforce a stringent progressive taxation system. \\
- Liberalize labor laws and wage levels \\
Enforce progressive registration tax on expensive cars to \\
be levied until the energy subsidy is removed
\end{tabular}

Adoption Of Renwable Resource Technology:

- Draft and implement legislation in the New and Renewable Energy Authority (NREA) in support of renewable resource technology

- Ensure low import trade barriers on technology of New and Renewable Energy (NRE), for e.g. solar, wind \& hydro

- Launch marketing campaign for NRE in Egypt

- Initiate technology training programs, and subsequent development of NRE curriculum, technology training, R \& $\mathrm{D}, \mathrm{S} \& \mathrm{~T}$ in local universities

- Egyptian government undertakes to re-invest part of its revenues (subsidy savings and/or increased taxes) in domestic energy infrastructure

- Provide incentives to convert from oil to Compressed Natural Gas (CNG) - power plants, industrial units, public transportation and vehicles

- Promote new domestic markets for solar and wind technology

- Provide incentives for private sector entry into solar and wind technologies market: e.g. conditional and limited tax holiday, cheap land, no tariffs

- Develop curriculum for solar and wind technology training, R\&D, S\&T in local universities

- Incorporate solar technology into public construction schemes

- Ensure low import trade barriers on solar and wind technology

\section{Attract Local \& Foreign Investments:}

- Provide incentives for private local and FDI entry into the energy sector as well as the NRE industries

- Privatization of the energy sector

- Formulate overall long term industrial plan with the collaboration of all the pertinent ministries

- Increase government transparency via marketing campaign, perfect knowledge, e-marketing, availability of free and updated information

- Reduction of bureaucracy and lengthy procedures
EXPECTED IMPACT

- Accommodate the poor-section of the population after the gradual withdrawal of subsidies

- Re-instate real energy prices \& eliminate price distortions in local market

- Reduce public debt

- Avoid inflationary forces after the removal/withdrawal of subsidies

- Provide government with necessary Funds to finance proposed schemes

- Increase income levels and welfare especially in the lower strata, \& emphasize job creation not subsidies

- Iron out share of the high income groups from the energy subsidy

- Indicate serious, high-level government support

- Foreign technology transfer

- Raise consumer and entrepreneur awareness of NRE

- Enhance human capital development in NRE

- Gradual establishment of a domestic NRE network

- Lowering domestic oil consumption and shifting to CNG

- Improve environment

- Encourage expansion of solar and wind energy markets in Egypt

- Enhance human capital accumulation through knowledge attainment, on-the-job training, in new and renewable energy technology
- Ensure the implementation of ambitious investment schemes with private \& public sector collaboration

- Enhance capital accumulation.

- Expand FDI involvement

- Transfer of technology

- Job creation and subsequent alleviation of unemployment

- Enhancement of human capital

- Increased market competition which would improve existing market mechanism, pricing \& cost structure

- Promote Egypt online 
The energy subsidy has the following implications: (i) The differential between the international price and the energy subsidy negatively impacts Egypt's public debt. The high levels of demand at artificially low market prices merely serve to increase debt, and in Egypt's case, public debt already exceeds $102 \%$ of $2005 \mathrm{GDP}^{27}$, a figure which does not leave many alternatives to a policy of strict fiscal austerity; (ii) The artificially low price encourages overconsumption compared to the case if consumers were paying real prices of oil and gas; (iii) The increase in domestic consumption, which constantly grows at local production and hence reduces export potential, denies Egypt's potential export revenue; (iv) Egypt might actually become a net importer of oil, with the obvious negative implication on its balance of trade; (v) Oil and gas are primary sources of energy and inputs for other industries, which further complicates the problem throughout the whole economy.

Another implication on welfare is the pollution caused by the exhaust emissions and their adverse effects on the environment. The urban environment in developing countries is a magnet for heavy pollution and low human health indicators. Recommended strategies take environmental concerns into consideration. As stated objectives of the Ministry of Energy and Electricity (MEE) and the New \& Renewable Energy Authority (NREA), strategies aim at converting domestic energy consumption from dirtier resources, such as crude oil, to cleaner and more environmentally sound resources, such as CNG, liquefied natural gas (LNG) and renewable resource technology. The discipline of renewable resource technology parallels a growing interest in the social cost of pollution. A recent project estimated that the monetary value of carbon dioxide pollution was between LE 358 to LE 1,738 per metric ton of carbon emissions. ${ }^{28}$ Encouragingly, Egypt has one of the lowest carbon dioxide emission rates in the MENA region because of its hydroelectric capacity, claiming only 127 million metric tons of $\mathrm{CO}_{2}$ emission in $2002 .{ }^{29}$ Although the Egyptian Ministry of Petroleum has adopted a strategy aimed at environment preservation and protection, and signed the Kyoto Protocol of the United Nations Framework Convention on Climate Change, it has yet to enforce that protocol to control carbon emissions. ${ }^{30}$ To counteract the exhaust problem, the "Pigouvian Framework" could be put into practice whereby polluters are penalized for their activities either by denying them registration until they remedy the problem or enforcing penalty taxes.

Dramatic increases in energy demand are an inseparable externality to economic growth. Particularly in developing countries, a $10 \%$ increase in disposable income often equals as much as a $20 \%$ increase in electricity consumption, and a $15 \%$ increase in natural gas consumption alone. ${ }^{31}$ Thus, the reverse is also true: opportunities for economic growth require higher demand levels on available energy. Be it industrial strength, private sector entrepreneurship or increased transportation services, developing societies require more energy to pursue their competitive and comparative advantages.

Hydroelectric power is generated from the River Nile at the Aswan High Dam, and remains to be the main source of renewable energy in Egypt. In the 1980s, the High Dam generated around 50\% of electricity for Egypt. However this rate has decreased to around $20 \%$ over the last ten years, although the demand for energy has increased. ${ }^{32}$

What makes increases in domestic consumption of energy so dangerous in developing countries is the price subsidy that generally accompanies them. Higher sales of a commodity at lower than market price creates lost revenues and unrealistic perceptions of the cost of energy, which in turn affects consumption behavior. Currently in Egypt, production of energy resources is lagging due to a gradual transition to natural gas and an increasingly outdated oil economy.

\footnotetext{
${ }^{27}$ CIA Fact Book, Ibid.

${ }^{28}$ Clarkson, Richard, Kathryn Deyes. Estimating the Social Cost of Carbon Emission. GES Working Paper 140. Available at www.hm-treasury.gov.uk.

${ }^{29}$ U.S. Department of Energy, www.eia.doe.gov/emeu/cabs/carbonemiss/chapter5.html

${ }^{30}$ U.S. Department of Energy, Ibid.

${ }^{31}$ De Moor, Andre and Peter Calamai, Subsidizing Unsustainable Development. Available on the World Wide Web at www.ecouncil.ac.cr/econ/sud/chap4.html

${ }^{32}$ U.S. Energy Information Administration, Country Analysis briefs, Egypt: Environmental Issues, Ibid.
} 
Aside from hydroelectricity, Egypt is boosting its use of other renewable energy such as solar and wind. The government in collaboration with USAID is undertaking a combined natural gas and solar power plant in Egypt. The proposed plant, which is funded by USAID and the Global Environmental Facility, would use solar energy during the day and natural gas at night, and is expected to start production in 2006. A few, small-scale solar projects under the patronage of UNDP Small Grants Program were also implemented to bring electricity to some rural areas in Upper Egypt. These projects, although limited and small in size, have contributed to a great improvement in the quality of life of the rural population. With respect to wind power, Egypt's New and Renewable Energy Authority is actively involved with the Danish and German governments to establish a large-scale wind project on the Red Sea Coast. ${ }^{33}$

In view of the current issues and potential conflict on water supply between the 10 countries on the River Nile, emphasis should be directed towards solar and wind more than hydro. Renewable resource technology in solar and wind is still making a shy entry into mainstream energy production in Egypt because the initial costs of importing the technology are high. However international aid for renewable resource technology is on the rise and may assist in producing sufficient energy to sustain developing growth rates.

The Egyptian government cannot undertake the overall development process by itself and is in dire need of private investment, both domestic and foreign. The government has realized that, and has already embarked on the path of re-organization as manifest in its serious privatization efforts, provision of investment incentives, to create an environment conducive to investment.

Furthermore, Egypt currently has a comparative advantage in the natural gas represented in its substantial natural gas reserves. It should therefore strive to enhance this advantage to be a competitive advantage and establish itself as a major player in the region through increased investments in the oil and gas sector. The launching of the Egypt-Jordan export pipeline is a positive step in the right direction, but more remains to be done. The foreign exchange earnings from the proposed exports would improve Egypt's balance of payments' situation, aid it in servicing its debts and provide it with necessary funds to be re-channeled for investment in this strategic sector. The increased investments would inevitably create more job opportunities, which in turn would have a favorable effect on Egypt's current unemployment problem.

\section{CONCLUSION}

The above strategies for sustainable development in Egypt's oil and gas sector are by no means easily attainable, especially since the gradual withdrawal of subsidies is a thorny issue, and attracting sufficient private and foreign investments is a major challenge. Egypt, being a price taker not a price maker, should therefore concentrate on reducing the price differential between its domestic prices and the international prices in order to alleviate its debt burden while at the same time enjoying any potential export windfall and investing it prudently to further develop its economy, and consequently avoiding the "Dutch Disease", instead of subsidizing the population at large for energy use.

It should be strongly emphasized that the most important underlying factor of development should be the ultimate welfare of the Egyptian society. And while some development strategies may in the short run initially create inequality and differentials, in the long run, adherence and commitment to the vision would ensure optimal welfare across the social spectrum. The proposed strategies target the revision of the existing outdated subsidy system with a more equitable social safety net. It is believed that the recommended strategies provide a starting point on the road to long-term sustainable growth and development of the strategic oil and gas sector, and subsequently the rest of the Egyptian economy.

\section{ACKNOWLEDGEMENTS}

Extensive research assistance provided by Homa Azarghoshasb, Abdula Mutualo, and Loubna Olama, Graduate Students at the Department of Economics of the American University in Cairo, Egypt.

33 Ibid. 


\section{BIBLIOGRAPHY}

1. Bertelsmann: http://www.bertelsmann-transformation-index.de, accessed December 2005.

2. Business Studies Series, The Petroleum Industry in Egypt: Investment \& Prospects, American Chamber of Commerce in Egypt (Am Cham), December 2003.

3. Cattan, Henry: The Law of Oil Concessions in the Middle East and North Africa, Oceana Publications, Inc., Dobbs Ferry, New York, 1967.

4. CIA Online, World Fact Book: Egypt, http://www.cia.gov/cia/publications/factbook/geos/eg.html accessed November 2005

5. Clarkson, Richard and Kathryn Deyes. Estimating the Social Cost of Carbon Emissions. Government Economic Service Working Paper No. 140, 2002. http://www.hm-treasury.gov.uk/media/209/60/SCC.pdf, accessed November 2005.

6. Colliti, Marcelo and Claudio Simeon: Perspectives of Oil and Gas: the Road to Interdependence, Kluwer Academic Publishers, London, 1996.

7. DeMoor, Andre and Peter Calamai. Subsidizing Unsustainable Development: Undermining the Earth with Public Funds. http://www.ecouncil.ac.cr/econ/sud/chap4.htm, accessed November 2005.

8. $\quad$ Egypt State Information Service, Energy Outlook on Egypt, accessed November 2005.

9. Gallon, A. Rebecca et al: Fundamentals of Oil and Gas Accounting, Pennwell Books, Tulsa, Oklahoma, Third Edition, 1993.

10. International Energy Outlook, U.S. Energy Information Administration, www.eia.doe.gov/emeu/cabs/carbonemiss/chapter5.html, accessed October 2005.

11. Middle East Economic Digest, Egypt: Petrochemicals, January 2003.

12. Ministry of Petroleum of Egypt: http://www.emp.gov.eg/ENGLISH/history.html, accessed November 2005.

13. Ministry of Petroleum Official Website: http://www.emp.gov.eg/ENGLISH/objectives.html, accessed 10.11.2005

14. Seda, Rodrigo Apache Egypt's Contribution to the Egyptian National Economy, The American University in Cairo, 2005.

15. UNDP Egypt: http://www.undp.org/Egypt, accessed November 2005.

16. UNDP EGYPT, Human Development Database, http://www.hdr.undp.org/statistics/data, accessed November 2005.

17. U.S. Department of Commerce, Country Commercial Guide FY2002: Egypt, www.world-digest.com/ Guides/eg accessed October 2005.

18. U.S. Department of Energy, Energy Information Administration, World Energy Use and Carbon Dioxide Emissions, 1980-2001. http://www.eia.doe.gov/emeu/cabs/carbonemiss/energycarbon2004.pdf, accessed November 2005.

19. U.S. Department of Energy, Energy Information Administration, Country Analysis briefs: Egypt, May 2005 www.eia.gov/emeu/cabs/egypenv.html, accessed December 2005.

20. World Bank, http://www.worldbank.org/Egypt/ElectricityandRenewables, accessed November 2005.

21. World Bank, www.worldbank.org/data/dataquery/html accessed November 2005.

22. World Energy Council, Energy in Egypt, 2002, www.worldenergy.org/wec-geis/wec-info/structureorganisation/ea/cairo/stats/eie.asp accessed November 2005. 
NOTES 